\title{
Challenges in identifying and serving students with special needs in Dodoma, Tanzania
}

\author{
Phidea H. Mapunda', Abich D. Omollo ${ }^{2^{*}}$ and Theodora A. L. Bali ${ }^{3}$
}

*Correspondence:
omolloabich24@gmail.com
${ }^{2}$ College of Education, The
University of Dodoma, P.O.
Box 523, Dodoma, Tanzania
Full list of author information
is available at the end of the
article

*Correspondence: omolloabich24@gmail.com University of Dodoma, PO. Box 523, Dodoma, Tanzania

\begin{abstract}
The purpose of this study was to assess if there is a functioning school-based system of assessment for identification and intervention programmes for children with special educational needs in pre-primary schools around Dodoma municipality. The study employed mainly qualitative research approach with some elements of quantitative research. Data were collected through interviews and documentary review. The study involved 28 participants who were purposively selected. Qualitative content analysis was used for data analysis. The study was guided by the socio-cultural theory. The findings of the study revealed that there were no special educational needs policy implementation frameworks necessary to enforce the provision of special educational needs for pre-primary children in Dodoma municipality. This has created a gap between the intended policy outcome and what is actually implemented at the municipal and school level. As a result, special educational needs for pre-primary children were mainly being carried out through ordinary classes without special educators or assistive learning devices. It was noted that the communication between schools and families of children with special educational needs was very poor. The study recommends that the current practices in the area of special educational needs require major improvement.
\end{abstract}

\section{Background}

The term special educational need was introduced in the beginning of the 21st century. The desire at that time was to move away from the use of older terminologies such as 'handicapped children' to find a generic description that would more suitably embrace the increasingly diverse group of children with problems in learning (Westwood 2011). According to Farrel (2003), a child has special educational needs if he or she has learning difficulties than the majority of children of the same age. This calls for special educational provisions to be made for such category of learners. The Department for Education and Skills (DfES) (2009) explains that children have a learning difficulty if they (a) have significantly greater difficulty in learning than the majority of the children of the same age; or (b) have a disability which prevents or hinders them from making use of educational facilities of a kind generally provided for children of the same age in schools within the area of the local education authority; or (c) are under compulsory school age and fall within the definition in (a) or (b) above, or would so do if special educational provision were not made for them.

(c) The Author(s) 2017. This article is distributed under the terms of the Creative Commons Attribution 4.0 International License (http://creativecommons.org/licenses/by/4.0/), which permits unrestricted use, distribution, and reproduction in any medium, provided you give appropriate credit to the original author(s) and the source, provide a link to the Creative Commons license, and indicate if changes were made. 
Hallahan and Kauffman (2003) identified categories of children who require special educational needs as: children with visual impairment, children with hearing impairment, children with intellectual impairment, and children with physical disabilities as well as the gifted. According to Bender and Shores (2007), children with special educational needs must be identified so as to plan for their intervention services. A process of identification and intervention of young children with special needs includes the following: (i) defining the problem such children are likely to have; (ii) planning an intervention for the child; (iii) implementing the intervention, and (iv) evaluating the child's progress (Bender and Shores 2007). Hus (2001) explains that the intervention for young children at risk for learning disabilities from pre-school through first grade is considered a promising approach to catch them before they fail. In the context of Tanzania, the government through the national policy on disability acknowledges that early identification followed by appropriate intervention is likely to minimise the impact of disability later in life (United Republic of Tanzania 2004). Such an effort shows how the government of Tanzania is committed towards provision of appropriate education for pre-primary children with special educational needs.

Children with abnormal patterns of development need a special education programme because general or mainstream education programmes cannot educate them effectively (Porter 2002; Shinn 2006). It is in this context that one of Tanzania's aims and objectives of pre-primary education is "to identify children with abnormal patterns of development or educational potentials and devise special programmes for them" (URT 1999, p. vi). Furthermore, Tanzania has also signed and ratified various international declarations that work towards equality in education. For instance, the Salamanca Agreement on special needs education that Tanzania ratified to in 1994 is a declaration that emphasizes the need for providing basic education to children with special educational needs (Mmbaga 2003); the UN Convention on the Rights of Persons with Disabilities (CRPD) signed in 1975 and ratified in 2009 (United Republic of Tanzania 2004; HakiElimu 2008); a convention on the rights of the child (CRC) (signed in 1989, ratified in 1991); convention against discrimination in education (CADE) (ratified in 1979); and the standard rules on the equalization of opportunities for persons with disabilities in 1993 (McAlpine 2008; HAKIELIMU 2011; Pima 2012). In 2004, the Government of Tanzania issued the national policy on disability and enacted the persons with disabilities act in 2010. Tanzania is also a signatory to the plan of action for the african decade of persons with disabilities and a member of African rehabilitation institute (ARI). Besides, Tanzania has ratified all UN treaties containing aspects of the right to education with the exception of the international convention on the protection of the rights of all migrant workers and members of their families (ICRMW) (HAKIELIMU 2011).

According to Tanzania Human Rights Report (2011), Tanzania is one of the countries with a larger than average number of persons with special needs. Basing on the 2002 population and housing census, it is revealed that there were 1.7 million children with disabilities living in Tanzania Mainland and just over 5000 children with disabilities in Zanzibar. These children have the following assortment of disabilities: physical handicaps (40\%); mental handicaps (19\%); multiple handicaps (14\%); and speech impairment (13\%) (McAlpine 2008). Meanwhile, the United Republic of Tanzania (2007) reports that, by 2007, Tanzania had 20 special primary schools, 231 integrated primary schools 
and 195 inclusive primary schools which form a total of 446 primary schools catering for children with special educational needs in the country.

According to HAKIELIMU (2008), Tanzania has three systems of education for children with special educational needs, namely, special schools, integrated schools, and inclusive education. The then Ministry of Education and Vocational Training (MOEVT) (2016) defines special schools, integrated units, and inclusive schools as follows: Special schools are those schools which provide education to only one category of children with special learning needs. On the other hand, integrated units are units for children with special learning needs which are attached to regular schools. Again, inclusive schools are regular schools which cater for learners with special learning needs in a regular inclusive classroom where such learners are assisted by a specialized teacher. MOEVT (2016) further reveals that Tanzania has been running educational services for learners with special educational needs through special schools, integrated units and inclusive schools for the following categories of learners with disabilities-deaf or children with impaired hearing who have 49 special schools/units (that is, 11 special schools, 38 units); the visually impaired have 37 special schools/units ( 3 special schools, 34 units); intellectually impaired have 160 special schools/units (5 special schools, 155 units); those with deafness-blindness have 8 special schools; those with physical impairment have 8 special schools/units ( 2 special schools, 6 units); and finally those with autism have 8 units. It should be noted that the data on schools/units provided above are for pre-primary and primary levels. Secondary schools which enrol children with disabilities are not included.

The existing literature on children with special educational needs outside Tanzania has focused on conceptualization of children with special educational needs and their diversity (Farrel 2003; DfES 2009; Hallahan and Kauffman 2003; Halliwell 2003). Some authors emphasize the importance of identifying children with special educational needs so as to plan for their intervention services (Bender and Shores 2007); to intervene before they fail (Hus 2001); and to facilitate their proper development alongside their typical growing peers (Fabian and Dunlop 2007). Similarly, available literature on children with special educational needs in Tanzania focuses on the taxonomy of services to these children (segregation, integration, and inclusion) (HAKIELIMU 2008; MOEVT 2016). Despite the fact that the impossibility of providing effective care and services to young children with special educational needs without establishing collaborative relationship with families is acknowledged (Klein et al. 2001), very few studies have been done in Tanzania to examine professional-parents relationship. Thus, this study sought to fill this gap.

This study was carried out by focusing on the following research questions: Firstly, does Dodoma municipality have a team of experts who can assess and identify pre-primary children with special educational needs? Secondly, what school-based intervention programmes for pre-primary children with special educational needs are available in Dodoma municipality? Thirdly, what special educational needs policy implementation framework for pre-primary children exists in Dodoma municipality? Lastly, how do schools involve families in assessment, identification, and intervention of pre-primary children with special educational needs in Dodoma municipality? 


\section{Theoretical framework}

This study is grounded in the socio-cultural theory (SCT). SCT is associated with works of the Russian psychologist Vygotsky (1896-1934). Vygotsky's socio-cultural theory describes learning as a social process and the origination of human intelligence in society or culture. The major theme of Vygotsky's theoretical framework is that social interaction plays a fundamental role in the development of cognition. Vygotsky believed that everything is learned on two levels. First, through our interaction with others, and through integrating what has been learnt into individual's mental structure. Second, the potential for cognitive development is limited to a "zone of proximal development" (ZPD). This "zone" is the area of exploration for which the learner is cognitively prepared, but requires help and social interaction to fully develop it (UNESCO 2003).

According to Klein et al. (2001), socio-cultural theory has been proved helpful in working with young children with special educational needs, since it emphasizes the importance of facilitating their learning through social mediation of the environment. This assistance is explained by Vygotsky (1978) through the concept of the zone of proximal development (ZPD). ZPD can be explained simply as the range of performance within which a child can function if he/she has support from other people who are more skilled. Mtahabwa (2007) adds that ZPD is the hypothetical, perpetually changing region in the child's mental realm as a result of the learning process defined by what the child can accomplish independently from what can be done only through help from adults or competent peers in a cultural group. The term used to refer to the provision of just the right amount of support within the ZPD is scaffolding (Klein et al. 2001). In this study, the scaffold is the right support necessary for the child with special educational needs to learn successfully. Appropriate scaffolding (Bailey and Wolery 1992) requires that adults be highly aware of children's current ability levels and that they closely observe children's behaviour so as to provide appropriate models and assistance. The Theory insists that adults who can read children's cues can determine just the right amount and type of support necessary for such children to perform the task. Adults then gradually reduce this support until the children can perform independently. By being aware of scaffolding as a specific strategy and matching it carefully with the child's existing skills, it can be a very effective support for a child with special educational needs.

The socio-cultural theory is appropriate to this study since it acknowledges through ZPD that there is a gap between what a child with special educational needs can manage to learn alone and what such a child can learn only when assisted with experts like special educator. ZPD emphasizes the importance of other people in facilitating the development of children with special educational needs by assisting them in the learning task that are beyond their level of understanding and ability. Furthermore, the Theory insists, through the concept of scaffolding that, for the learning to be effective, assessment should be conducted to identify the right amount and type of intervention programme necessary for successful learning of children with special educational needs. In other words, scaffolding helps to determine placement of a child with special educational needs in education settings like special schools, integrated education or inclusive education. 


\section{Methodology}

This study was conducted in both public and private selected pre-primary schools in Dodoma municipality. In the study, twenty-eight (28) participants were involved including ten pre-primary class teachers (from both public and privately owned schools), ten heads of schools (both public and private), one early childhood education officer, one special educational needs officer, 1 head of special school, and five parents as indicated in Table 1. Data were gathered using semi-structured interviews and documentary review. Trustworthiness in this study was achieved by conducting a peer examination and debriefing. An expert (the researcher) gave a constructive feedback concerning the research methods and analysis of the findings. Moreover, the interviews were conducted exclusively by using Kiswahili language to facilitate easy communication with participants in the field and then the interview responses were translated from Kiswahili language into English language after the interviews. The use of Kiswahili language to conduct interviews helped the participants to express themselves freely as they were more conversant with it than the English language.

The collected data were analysed using qualitative content analysis (Mayring 2000). Mayring argues that qualitative content analysis applies the procedures of inductive categories development. The main idea of the procedure is, to formulate a criterion of definition, derived from theoretical background and research question, which determines the aspects of the textual material taken into account. Following this criterion, the material is worked through and categories are tentative and step by step deduced. Within a feedback loop those categories are revised, and are eventually reduced to main categories and checked in respect to their reliability. If the research question suggests quantitative aspects (e.g., frequencies of coded categories) the quantitative steps of analysis are followed to supplement qualitative data.

\section{Findings and discussion}

The research findings are presented according to the research questions as summarized in Table 2 showing theme, categories, and sub-categories of the study.

\section{Functioning school-based system for identifying pre-primary children with special educational needs}

The general objective of this study was to assess whether there was a functioning schoolbased system of assessment for identification and intervention programmes for children with special educational needs in pre-primary schools. For this reason, therefore,

Table 1 Basic characteristics of the study respondents. Source Field Data (2014)

\begin{tabular}{llll}
\hline S/n & Categorization & Number & Sex \\
\hline 1 & Special needs education officer & 1 & Female \\
2 & Early childhood education officer & 1 & Female \\
3 & Head teachers (from both public and private owned pre-schools) & 10 & Eight females, two males \\
4 & Class teachers (from both public and private owned pre-schools) & 10 & All were females \\
5 & Head of special school & 1 & Male \\
6 & Parents & 5 & Three females, two males
\end{tabular}


Table 2 Theme, categories, and sub-categories of the study

\begin{tabular}{|c|c|c|}
\hline Theme & Categories & Sub-categories \\
\hline \multirow[t]{4}{*}{$\begin{array}{l}\text { Identification and services to } \\
\text { pre-school children with special } \\
\text { educational needs }\end{array}$} & Special educational needs experts & $\begin{array}{l}\text { Special needs educators } \\
\text { General education teachers } \\
\text { Early childhood education teachers }\end{array}$ \\
\hline & $\begin{array}{l}\text { School-based intervention pro- } \\
\text { grammes }\end{array}$ & $\begin{array}{l}\text { Special schools } \\
\text { Inclusive schools } \\
\text { Ordinary schools }\end{array}$ \\
\hline & Policy implementation frameworks & $\begin{array}{l}\text { Lack of policy implementation } \\
\text { framework } \\
\text { Varied and improper delivery of } \\
\text { policy }\end{array}$ \\
\hline & Family involvement & $\begin{array}{l}\text { Poor communication and interaction } \\
\text { Mistrust between parents and } \\
\text { teachers } \\
\text { Underrated ability of parents }\end{array}$ \\
\hline
\end{tabular}

ascertaining the availability, number and types of pre-primary children with special educational needs in these schools (ordinary pre-primary classes) was essential. From the 21 interviewed informants (i.e., class teachers and heads of schools) and the review of admission register for pre-primary children, it was revealed that there were five types of special educational needs categories in ten mainstream pre-primary classes, namely children with visual impairment, speech impairment, hearing impairment, intellectual disability, and physical disabilities. Table 3 presents the number and types of pre-primary children with special educational needs. The distribution of children with special educational needs from pre-primary schools visited by the researcher is shown in Table 3 that indicates two (2) pre-primary children in private schools, eleven (11) pre-primary children in public-private owned special school, and seventeen (17) pre-primary children within public schools.

As shown in Table 3, it is clear that there are pre-primary children with special educational needs in Dodoma municipality. Out of 30 pre-primary children with special educational needs, only 11 (36.66\%) were found in special school, 3 (10\%) were in inclusive setting with one special educator; however, majority, that is, 16 (53.33\%) children were in ordinary pre-primary classes without a special educator. Hence, they were not receiving

Table 3 The number and types of pre-primary children with special educational needs. Source Field Data (2014)

\begin{tabular}{|c|c|c|c|c|c|c|c|c|c|c|c|c|c|}
\hline \multirow[t]{3}{*}{ Types of disability } & \multicolumn{10}{|c|}{ Schools } & \multirow{3}{*}{$\begin{array}{l}\text { Public-private owned } \\
\text { Dodoma Viziwi }\end{array}$} & \multirow[t]{3}{*}{ Total } & \multirow[t]{3}{*}{$\%$} \\
\hline & \multicolumn{5}{|c|}{$\begin{array}{l}\text { Public owned } \\
\text { schools }\end{array}$} & \multicolumn{5}{|c|}{$\begin{array}{l}\text { Private owned } \\
\text { schools }\end{array}$} & & & \\
\hline & $A$ & B & $C$ & D & $\bar{E}$ & $F$ & G & $\mathrm{H}$ & $\mathrm{I}$ & J & & & \\
\hline Visually impaired & 3 & 2 & 0 & 3 & 1 & 0 & 0 & 0 & 0 & 0 & $\mathrm{~N} / \mathrm{A}$ & 9 & 30 \\
\hline Hearing impaired & 1 & 0 & 0 & 1 & 0 & 0 & 0 & 0 & 0 & 0 & 11 & 13 & 43.3 \\
\hline Mute & 0 & 0 & 1 & 0 & 0 & 0 & 0 & 0 & 0 & 0 & $\mathrm{~N} / \mathrm{A}$ & 1 & 3.3 \\
\hline Physical disability & 0 & 0 & 0 & 2 & 2 & 0 & 1 & 0 & 1 & 0 & $\mathrm{~N} / \mathrm{A}$ & 6 & 20 \\
\hline Intellectual disability (ies) & 0 & 0 & 1 & 0 & 0 & 0 & 0 & 0 & 0 & 0 & $\mathrm{~N} / \mathrm{A}$ & 1 & 3.3 \\
\hline Total & 4 & 2 & 2 & 6 & 3 & 0 & 1 & 0 & 1 & 0 & 11 & 30 & 100 \\
\hline
\end{tabular}

N/A refers to "not applicable" because the school is a special school enrolling only children with hearing impairment 
appropriate education as per their educational needs. This fact is justified by the data summarized in Table 3 which indicates that only one of the pre-primary class teachers from the sampled schools had specialization in special educational needs.

From the Table 3 above, the letters A-E represent public schools while the letters from F-J represent private schools. In each school, the number and type of disability of pupils are indicated. The entity 0 indicates the absence of children with that type of disability. For instance, school $\mathrm{C}$ has no visually impaired children in pre-primary class.

\section{Availability of team of experts for identifying pre-primary children with special educational needs}

The research question one sought to establish if Dodoma municipality had a team of experts who could assess, identify, and devise programmes for pre-primary children with special educational needs. The study found that out of 30 pre-primary children with special educational needs, only 11 (36.66\%) were in special school, $3(10 \%)$ were in inclusive setting with one special educator; however, majority, that is, 16 (53.33\%) children were in ordinary pre-primary classes without a special educator. Hence, as it can be deduced from the findings, these children were not receiving appropriate education as pertinent to their educational needs. This fact is justified by the data summarized in Table 4 which indicates that only one out of the 10 pre-primary class teachers from the sampled schools had specialization in special educational needs. According to the United Republic of Tanzania (2013), the total number of pre-school children in Dodoma municipality was 8377 composed by (4168 males and 4209 females). This implies that 30 children with special educational needs from schools that were physically visited by the researcher forms $0.35 \%$ of all children in pre-schools in Dodoma municipality. Indeed, this an under-representation of children with special education needs in Dodoma. It also shows structural deficit in the special education teachers training as reported by the study informant response below:

...to identify and devise special programme for children with special needs education are very few; in addition, the college which produces these experts for the whole country is Patandi only. Other colleges only teach special needs education theoretically hence their graduates cannot conduct assessment exercises.

The findings of this study on this particular regard concur with that of informants HAKIELIMU (2008) which found a total of 48 students with disability in two districts in Tanzania but who had no teacher trained for special/inclusive education. This

Table 4 Pre-primary class teachers education specialization. Source Humphrey (2014)

\begin{tabular}{|c|c|c|c|c|c|c|c|c|c|c|c|c|}
\hline \multirow[t]{3}{*}{ Education specialization } & \multicolumn{10}{|c|}{ Schools } & \multirow[t]{3}{*}{ Total } & \multirow[t]{3}{*}{$\%$} \\
\hline & \multicolumn{5}{|c|}{ Public owned schools } & \multicolumn{5}{|c|}{ Private owned schools } & & \\
\hline & A & B & C & D & E & $\mathrm{F}$ & G & $\mathbf{H}$ & I & $J$ & & \\
\hline General education & & & & $\checkmark$ & & & & $\checkmark$ & & & 2 & 20 \\
\hline Early childhood education & $\checkmark$ & $\checkmark$ & $\checkmark$ & & & $\checkmark$ & $\checkmark$ & & $\checkmark$ & $\checkmark$ & $\checkmark$ & 70 \\
\hline Special educational needs & & & & & $\checkmark$ & & & & & & 1 & 10 \\
\hline Total & 1 & 1 & 1 & 1 & 1 & 1 & 1 & 1 & 1 & 1 & 10 & 100 \\
\hline
\end{tabular}


constrained the effective provision of assessment and intervention services for children with disabilities in these districts. Similar findings by Najjingo (2009) show that only 1050 (0.85\%) out of 122,904 primary school teachers in Uganda had been trained to help children with disabilities. Similar observation was identified in Nigeria by Ajuwon (2008) who investigated various initiatives geared to improve the special needs education sector. His findings indicate that dually-trained special educators (i.e., those holding certification in an area of special education and a subject-matter discipline) were not properly deployed to work with students with disabilities. The critical shortage of special needs experts is common not only in developing countries but also in some developed one. Kulagina (Oreshkina 2009) found that lack of qualified teachers was undermining the quality of special education in Russia. Only $10 \%$ of the teachers in special schools have a degree in special education. The situation in regular schools is even more challenging.

Assessment for identification of pre-primary children with special needs requires a multi-disciplinary assessment team that comprises specialist teachers, psychologists, speech and language specialists, physical and occupational therapists, counsellors, and other relevant professionals (Charema 2010). However, as the findings of the present study show, it can be said that there was no "team of experts" available for Dodoma municipality. This implies that there has been no deliberate assessment for identification exercise with regard to children with special educational needs in the area of the study. Surprisingly, even special schools like Dodoma Viziwi were found not working in team with other special needs specialists.

Table 4 shows the education specialization of pre-primary class teachers namely teachers with general education, teachers specialized in special educational needs, and teachers with early childhood education. For instance, the Table shows that there are two teachers teaching pre-primary classes in school D and $\mathrm{H}$ who were trained in general education.

\section{School-based intervention placements for pre-primary children with special educational needs}

The second question of this study was geared to find out the school-based intervention placements available for pre-primary children with special educational needs in Dodoma municipality. Responses from the informants showed that there were three school-based intervention programmes namely, inclusive classes, ordinary classes and special schools. First, inclusion with special educator: The study found that there were some children with special educational needs studying with their normal peers in general education classrooms under the guidance of a special educator. The researcher visited one of the six inclusive pre-primary schools, (school "E" as indicated in Table 3) and found three children in pre-primary class with special educational needs studying with their peers. Second, special schools: The study found that children with severe impairment were enrolled in special schools that were providing special educational needs in relation to the child's disability. The study also found that there were only two special schools in Dodoma municipality; however, parents were being advised by school management to take their children to special schools outside Dodoma region for children whose needs may not be met effectively in these schools. The researcher visited one of such special schools particularly for the hearing impaired children located few kilometres from 
Dodoma municipal office along Dodoma-Morogoro highway. Third, inclusion in ordinary classes with no special educators: children with different levels of disabilities were also found in ordinary classrooms taught by general education teachers. The study found that some children were receiving their education in ordinary classrooms but without any support from special educator and they were without special instruments that could have assisted them in their learning. With exception of children in special school, (11 children) and those in inclusive classrooms under the guidance of a special educator ( 3 children in school E), the rest, that is, 16 children with special educational needs were found in regular classrooms with neither any special educator nor assistive learning devices for children with special educational needs (see Table 3). Teachers reported that parents normally 'dumped' their children with special educational needs in ordinary classes even if they were told that there was no special educational needs educator.

The findings of this study are in line with other studies which investigated intervention placement programmes in special schools. For example, the Government of Russian Federation (Oreshkina 2009) observed that special needs education in Russia were being offered in special pre-schools, schools, and boarding schools, as well as special groups and classes in regular pre-schools and schools. In relation to inclusive education settings, this study finding also concurs with many other studies. A study by KrohnNydal (2008) found that the government of Tanzania together with UNESCO initiated inclusive education in five pilot schools in 1997. Also the then Ministry of Education and Vocational Training was implementing the programme in about 140 schools in nine regions all over the country. This study found that the special educational needs that are provided in inclusive setting have policy backing. For instance, in Tanzania, the persons with disabilities act of 2010 and national policy of disability of 2004 both declare that children with disabilities shall have education in inclusive settings (United Republic of Tanzania 2004, 2010). Similarly, in Nigeria, the national policy on education promotes inclusive education (Ajuwon 2008).

A study by Gebhardt et al. (2013) in Austria found that children with special needs who attend general pre-schools usually come to resource rooms to work with special educators while they are included in general classrooms for studying other subject areas. However, the difference between the findings of the present study and the previous ones could be explained in terms of the difference in resources support. While previous studies show that children with special needs are afforded with necessary resources for their learning, the present study shows the opposite. In Dodoma municipality, children with special needs who attend ordinary classes are taught by general education teachers who have never attended special education trainings. Moreover, they never attend resource rooms.

While Charema (2010) supports inclusion, he however argues that developing countries have not yet arrived at the point where every school in each and every developing country would have to implement inclusive education. Because it will require all teachers in regular schools to be prepared to teach all children irrespective of the children's individual differences. All learning and other school activities should be accessible to all children. Curriculum materials and assessment procedures should be adapted to suit and reflect the background and experience of all learners. Thus, it can be said that what is practised as inclusion in Dodoma municipality is neither integration nor inclusion. 
Integration is described as an 'assimilationist' process, when the placement of the child depends on his/her ability to fit a largely unchanged school environment. On the other hand, inclusion involves a restructuring of mainstream schooling that every school can accommodate every child irrespective of the disability (Avramidis and Norvich 2002). Therefore, improper implementation of inclusive education as observed in this study's findings means that children with disability will have adjustment problems in regular classes (Obaseki and Osagie-Obazee 2009).

\section{Existence of special educational needs policy implementation framework}

The third question sought to explore the existence of a special educational needs policy framework for pre-primary children. The study indicated that special educational needs were guided by the national education and training policy of 1995, 2014 where access to education is theoretically guaranteed to every citizen regardless of sex, race, ethnicity, religion, disability, and social and economic status; however, there is no policy implementation framework, law or guidelines at the municipality and school level. Thus, what was to be done by the heads of primary schools, special or early childhood education officers/teachers in the municipality or pre-primary class in identifying and then providing appropriate education and other programmes to children with special educational needs was never officially communicated to them. The then Ministry of Education and Vocational Training (now the ministry of education, science and technology) had not issued any guideline for the different components of the chain of actions, stipulating how the special educational needs coordinators or officers and schools at district level should provide such special educational needs. This lack of policy implementation framework has led to the variation in the implementation of assessment for identification and intervention programmes for pre-primary children with special educational needs hence its provision depends on each officer's determination.

The findings of this study are consistent with other international studies. For instance, Nilsen (2011) found in the study he conducted in Norway that the policy was ambiguous when it came the question of the locus of authority, distribution of responsibility, and the local scope for action, then some local authorities and schools adopted practice according to their own culture and tradition, even where this was contrary to the intentions of the government. Similarly, a study by Nordahl and Hausstätter (2009) uncovered an inadequate understanding and practice of national policies on special needs in several municipalities. The variation in the scope of special education was associated with local differences in the interpretation and practice of policy. The local interpretations of the guidelines may in some cases deviate from the intentions of the law, creating a situation in which the formal requirements for special education are not met.

Lack of special needs education implementation framework implies that teachers have nowhere to report to even if they find that a child needs special education. Moreover, there are no directions/laws that compel special education coordinators or schools to have a team of experts on special needs in the schools or municipality. The lack of concrete guidelines on how to do assessment for identification and intervention for children with special needs in Dodoma municipality hinders the successful implementation of special needs education. Other studies concur that the absence of respective legislation, political directives, and non-implementation of the existing Acts are the factors that 
impede implementation of educational policies that guarantee access to special needs education (Oreshkina 2009; Najjingo 2009; UNICEF/UNESCO 2007; Berhanu 2006). HAKIELIMU (2008) attributes the lack of special educational needs implementation framework to the absence of political will to help children with disabilities. Other factors are limited participation of all stakeholders in policy formulation, and weakness on the part of the government to disseminate as well as raise awareness on the existing laws.

Within the context of this study, it can be summarized that there is lack of political will, for the Tanzania government to seriously implement all what it has signed and ratified in different international conventions and protocols to implement different issues related to the handling of children with special needs. What is obvious is that the Government is responding to external pressure from their development partners such as UN agencies, developed countries, etc. to show the world that they it is not left behind when it comes to special needs education hence they have rectified but not yet ready to provide special needs education because of lack of necessary resources to do so. For example, it is 20+ years since the ETP of 1995 came into force but nothing has changed about the policy and it is not helping children with special needs.

\section{Family involvement in assessment for identification and intervention programmes}

The fourth question aimed at finding out the extent to which families were involved in assessment for identification and intervention of their pre-primary children with special needs education. Through interviews, all categories of research informants revealed that there was little involvement of parents on issues relating to assessment for identification and intervention for their pre-primary children with special needs education. On this particular regard one parent said that:

"...they normally invite me, I went there once but when I arrived at the school I found that I was the only parent who had responded to the invitation hence I decided to go back home without saying goodbye and I have never gone there again".

The study also found that parents were not helping their children with their homework. When asked how often he was helping his child with homework, one parent said "I normally remain home thus I cannot understand what he has learned at school". The study also revealed that, even in special school, there was poor involvement of parents. Through interview, the Head of one of the special schools said that as a school, they hadn't called parent-school meeting for about 2 years. Although they used to arrange for parent-school meetings, the parents' responses were usually very poor such that they kept postponing such meetings.

The study also revealed that most of the teachers underestimated the contribution that parents could provide in relation to identification and intervention programmes for their children with special educational needs. One class teacher reasoned that the parents have no any knowledge on identification or cannot advise how and what should be taught to their children in relation to their disability.

Also the study found that there was mistrust and ill feeling between parents and teachers to the extent that parents did not accept the advice from the school. A class teacher of school C commented: 
"If we advise parents to take their children to schools that are appropriate in relation to their educational needs, some of them complain to government officials, some do not accept teachers' advice thinking that their children are being discriminated. You'll find that a parent is denied of the opportunity for the reason that the school isn't appropriate for the child but the next day you find the same child in the class, if you ask, he/she will tell you that it is my father who told me to come"

Furthermore, the researcher found that shortage of fund was the main reason as to why the school did not make significant effort to involve parents in the education of their children with special needs. On this, the Head of special school argued that:

"We don't have fare to give to the parents so that they come to school to visit a and see what is being done for the education of their children with disabilities. With regard to the children. We are also supposed to bring them to school and take them back home during the holidays but because the school has no enough funds that has now become the responsibility of their parents"

The above quotations suggest that there was poor involvement of parents in issues concerned with the services that were being provided to their children with special educational needs. Furthermore, schools were seen to underrate the value and ability of parents' contribution to information that could help them in assessment for identification and development of intervention programmes for the children with special needs. Parents also seemed not to be so much concerned with their children's disabilities and some thought that it was the burden of the school to take care of their children.

These findings are in line with other studies that show poor involvement of parents in children with special needs when it comes to their education. For instance, a study by Mukuria and Obiakor (2004) in Nigeria and that by Alquraini (2010) in Saudi Arabia found that many parents were excluded from their children's education. HAKIELIMU (2008) also had similar observation that teachers were complaining that some parents of children with special educational needs were a barrier to the education of their children with disability because they abandoned their children once they were enrolled in schools. The poor turn up by parents is also consistent with a study conducted by Martinez and Young (2011) in Texas to find out whether parents were invited to and participated in the follow-up meeting to monitor their children with special needs progress. In this study, $48 \%$ of the findings indicated that parents were rarely or never invited and not surprisingly then that the remaining $56 \%$ indicated that parents never or rarely participated in follow-up responses to intervention meetings. Taub (2006) found that not all parents are able to attend or are interested in attending meetings about their children's education.

Parent's poor participation in their children's special needs education affairs is reflected in the findings of the study by Obaseki and Osagie-Obazee (2009) that some parents were ashamed of their children with disability. Carter (2006) found in Thailand that more than $85 \%$ of the children with disabilities were from families considered at or below the poverty level and/or from families with little or no formal education. Taub (2006) added that work schedules may prevent parents from being involved in aspects of their children's development and education. Poor beliefs were also found by basic needs review (2004) as contributing factors. Previously, (before awareness education) parents 
thought that paying school fees for their children with special needs was a complete waste of time. Mulholland and Blecker (2008) findings conclude that most educators had little or no training in family involvement and pre-service teacher training in this area is at best limited. Hence, it is advised that when parents feel that they are being heard, and that what they have to contribute is honoured, they will actively involve themselves in school contexts (McCloskey 2010).

\section{Conclusions}

The Tanzania government's intentions to ensure that all children have an equal and equitable opportunity to learn regardless of one's condition is commendable; however, the situation is much worse when it comes to the provision of assessment for identification and intervention services for children with special educational needs in the Dodoma municipality. The reasons for such poor implementation of special educational needs are the absence of a team of experts due to a critical shortage of special educational needs specialist teachers and total absence of other special needs professionals. Moreover, poor school-families involvements as well as the lack of policy implementation framework and guidelines are among the factors that hinder successful provision of special educational needs for pre-primary children. In fact, the lack of the efficient policy implementation framework, guidelines and directives necessary to enforce the provision of special educational needs has created a gap between the intended policy and what is actually implemented at the municipal and schools level. This has resulted in a lack of special education services for most of the pre-primary children with disabilities. It can therefore be concluded that it will be impractical, if not impossible to attain equal access to education by all children if the current practices in the area of special educational needs are not improved.

To rectify this improper implementation of special educational needs, the government of Tanzania needs to do what Berhanu (2006) suggested: (a) to empower schools by financing and allocating resources necessary for running special educational needs. Enough funds will enable schools to procure learning resources appropriate for children with special educational needs; (b) provide special educational needs policy directives to local or school level stipulating how the special educational needs shall be provided; (c) provide social and physical set-up of the school which is supportive to both children with or without disability especially in inclusive schools; (d) school staff both teaching and non-teaching should be professional, and competent in handling children with special educational needs whether in special setting or inclusive setting and should be provided with in-service training on issues of inclusiveness as well as special educational needs on continual basis; (e) government should provide technical aids for children with special educational needs. For instance, in theory, the government of the United Republic of Tanzania (2004) acknowledges that people with disabilities require technical aids to enhance their functional ability. Such aids include white cane, hearing aids, and writing frame with stylus, hats, and sunglasses. Other technical aids are tricycles, motorized three wheelers, modified car and braillies. However, in practice, these technical aids or assistive learning devices are short in supply in most of the schools; and (f) government should encourage both parents and schools to have the right attitude by respecting and appreciating the contribution of each other on education of the children 
hence schools should engage parents in decision-making. Russo et al. (2009) argue that the schools on their part should keep the lines of communication open by working with parents and other service providers as well as understanding parents' dilemmas. Parents' failure to heed to teachers' advice of sending children to special or designated schools should not warrant judgmental remarks insinuating carelessness on parents' side. This is because, parents' may just be protecting their children or may not have the means to ferry their children to those six designated schools given that these children cannot not commute alone. It would be good if all educators in Dodoma municipality were provided with inclusive education so that they could provide appropriate education to children with special educational needs. In that way, all schools could enable children with special educational needs study with their peers with whom they play daily at minimal costs and disturbances.

\section{Authors' contributions}

This article was taken from PH (student of from St. John's University of Tanzania by then) masters dissertation supervised by TB (PhD). AO was involved in converting dissertation into publishable article. All authors worked equally on the first and final draft of this manuscript. All authors read and approved the final manuscript.

Author details

${ }^{1}$ Umonga Secondary School, P.O. Box 3466, Dodoma, Tanzania. ${ }^{2}$ College of Education, The University of Dodoma, P.O. Box 523, Dodoma, Tanzania. ${ }^{3}$ St. John's University of Tanzania, P.O. Box 47, Dodoma, Tanzania.

\section{Acknowledgements}

We owe a debt of gratitude to the Management of the St. John's University of Tanzania for assigning us to work on this study together and for encouraging us to publish its findings. Moreover, we are very grateful to the participants for the breadth of information they shared with us; without their willingness this study would have been impossible.

\section{Competing interests}

The authors declare that they have no competing interests.

Availability of data and materials

Data and materials are available.

\section{Consent for publication}

Not applicable.

Ethics approval and consent to participate

Documents attached includes letter granting data collection provided by Dodoma municipality, Research consent form and Research clearance letter.

\section{Funding}

Research funding was private.

\section{Publisher's Note}

Springer Nature remains neutral with regard to jurisdictional claims in published maps and institutional affiliations.

Received: 5 March 2017 Accepted: 12 October 2017

Published online: 23 October 2017

\section{References}

Ajuwon, P. M. (2008). Inclusive education for students with disabilities in Nigeria: Benefits, challenges and policy implications. International Journal of Special Education, 23(3), 11-25.

Alquraini, T. (2010). Special education in Saudi Arabia: Challenges, perspectives, future possibilities. International Journal of Special Education, 25(3), 139-147.

Avramidis, E., \& Norwich, B. (2002). Teachers'attitudes towards integration/inclusion: A review of the literature. European Journal of Special Needs Education, 17, 129-147.

Bailey, D. B., \&Wolery, M. (1992). Teaching infants and preschoolers with disability (2nd ed.). New York: Macmillan Publishing Company.

Bender, W. N., \& Shores, C. (2007). Response to intervention: A practical guide for every teacher. Thousand Oaks: Corwin Press.

Berhanu, G. (2006). Favourable factors to enhance participation and equality. Sweden (Monograph): Specialpedagogiska Institutet.

Carter, S. L. (2006). The development of special education services in Thailand. International Journal of Special Education, $21(2), 32-40$. 
Charema, J. (2010). Inclusive education in developing countries in the sub Saharan Africa: From theory to practice. International Journal of Special Education, 25(1), 87-103.

Department for Education and Skills. (2009). Special educational needs code of practice. London: DfES.

Fabian, H., \& Dunlop, A. W. (2007). Outcomes of good practice in transition processes for children entering primary school. Working paper 42. The Hague: Bernard van Leer Foundation.

Farrel, M. (2003). Understanding special educational needs, a guide for student teachers. London: Routledge Falmer.

Gebhardt, M., Krammer, M., Schwab, S., Rossmann, P., \& Gasteiger Klicpera, B. (2013). What is behind the diagnosis of learning disability in Austrian schools? An empirical evaluation of the results of the diagnostic process. International Journal of Special Education, 28(1), 1-18.

HAKIELIMU (2008). Do children with disabilities have equal access to education? A research report on accessibility to education for children with disabilities in Tanzanian schools. http://www.hakielimu.org/files/publications/document131Children_disabilities.pdf. Accessed 12 Nov 2013.

HAKIELIMU (2011). Litigating the right to education in Tanzania: Legal, political, and social considerations and potential applications. http://www.right-to-education.org/sites/right-to-education.org/files/resource-attachments/Hakielimu_Litigating_the_Right_to_Education_in_Tanzania_2011.pdf. Accessed 5 May 2016.

Hallahan, D., \& Kauffman, J. (2003). Exceptional learners (9th ed.). Needham Heights: Allyn \& Bacon.

Halliwell, M. (2003). Supporting children with special educational needs: A guide for assistants in schools and pre-schools. London: David Fulton Publishers Ltd.

Humphrey, P. M. (2014). Assessment of special needs education in pre-primary schools in Tanzania: the case of dodoma municipality. Unpublished Dissertation of Masters of Arts in Education of St. John's University of Tanzania.

Hus, Y. (2001). Early reading for low-SES minority language children: An attempt to 'catch them before they fall'. Folia Phoniatrica et Logopaedica, 53(3), 173-182.

Klein, M. D., Cook, R. E., \& Richardson-Gibbs, A. M. (2001). Strategies for including children with special needs in early childhood settings. New York: Thomson Learning Inc.

Krohn-Nydal, A. (2008). The development of inclusive education in the Tanzanian primary school. Master thesis for the master of philosophy degree in comparative and international education, Institute for Educational Research UNIVERSITETETI OSLO

Legal and Human Rights Centre. (2011). Tanzania Human Rights Report 2010. Dar es Salaam: Legal and Human Rights Centre.

Martinez, R., \& Young, A. (2011). Response to intervention: How is it practiced and perceived? International Journal of Special Education, 26(1), 44-66.

Mayring, P. (2000). Qualitative content analysis [28 paragraphs]. Forum qualitative sozialforschung/forum: Qualitative social research, 1(2), Art. 20. http://www.qualitative-research.net/index.php/fqs/article/view/1089/2385. Accessed 16 Aug 2017.

McAlpine, K. (2008). The situation of children with disabilities in Tanzania, a consultation with children, adults \& practitioners: A briefing paper for the child rights curriculum for professionals who deal with early childhood development (ECD) in Tanzania.

McCloskey, E. (2010). What do I know? Parental positioning in special education. International Journal of Special Education, 25(1), 161-181.

Ministry of Education and Vocational Training. (2016). Special education. http://www.moe.go.tz/index.php?option=com_ content\&view=article\&id=1585:special-education\&catid=299:special-edu. Accessed 9 May 2016.

Mmbaga, D. R. (2003). The inclusive education in Tanzania and global discourse, papers in education and development (pp. 1-23). Dar es Salaam: University of Dar es Salaam.

Mtahabwa, L. (2007). Pre-primary educational policy and practice in Tanzania: Observation from urban and rural preprimary schools, unpublished PhD (education) Thesis. University of Hong Kong.

Mukuria, G., \& Obiakor, F. E. (2004). Special education issues and African diaspora. Journal of International Special Needs Education, 7, 12-17.

Mulholland, R., \& Blecker, N. (2008). Parents and special educators: Pre-service teachers' discussion points. International Journal of Special Education, 23(1), 48-61.

Najjingo, H. (2009). Challenges of accessing all-inclusive education services by children with disabilities (Cwds): A case of Mijwala Sub-County Ssembabule District. Unpublished Dissertation of Masters of Arts, Social Sector Planning and Management of Makerere University.

Nilsen, S. (2011). The chain of actions in special education —-the relationship between national guidelines and municipal follow-up: An evaluation based on a case study from one Norwegian municipality. International Journal of Special Education, 26(1), 33-61.

Nordahl, T., \& Hausstätter, R. (2009). The conditions, contributions and results of special education. Elverum: Høgskolen i Hedmark.

Obaseki, F. N., \& Osagie-Obazee, G. E. (2009). The intellectual disabled (mentally impaired) in the inclusive type of education: Problems and implications. Education Journal of Counseling, 2(2), 228-234.

Oreshkina, M. (2009). Education of children with disabilities in russia: On the way to integration and inclusion. International Journal of Special Education, 24(3), 110-161.

Pima, M. J. (2012). Six years of implementing national policy on disability in Tanzania: A study of primary school teachers' perspectives on influence of the policy in special needs education. Master's Thesis, University of Oslo.

Porter, L. (2002). Educating young children with additional needs. Sydney: Allen \& Unwin.

Russo, C. J., Osborne, A. G., Jr., Massucci, J. D., \& Cattaro, G. M. (2009). The law of special education and non-public schools: Major challenges in meeting the needs of youth with disabilities. Plymouth: Rowman \& Littlefield Education.

Shinn, M. R. (2006). Curriculum-based measurement: Assessing special children (3rd ed.). New York: The Guilford Press.

Taub, D. J. (2006). Understanding the concerns of parents of students with disabilities: Challenges and roles for school counselors. Professional School Counseling Journal, 10(1), 52-57.

UNESCO (2003). Vygotsky's sociocultural theory. http://portal.unesco.org/education/en/ev.php-URL_ID=26925\&URL_ DO=DO_TOPIC\&URL_SECTION=201.html. Accessed 16 May 2016. 
United Nations Children's Fund/United Nations Educational, Scientific and Cultural Organization. (2007). A human rightsbased approach to education for all: A framework for the realization of children's right to education and rights within education. New York: UNICEF.

United Republic of Tanzania. (1999). Pre-primary school education syllabuses: Children's activities. Dar es Salaam: Ministry of Education and Culture/Tanzania Institute of Education.

United Republic of Tanzania (2004). National Policy on Disability. Dar es Salaam: Ministry of Labor, Youth Development and Sports. http://www.tanzania.go.tz/egov_uploads/documents/NATIONAL_POLICY_ON_DISABILITY_sw.pdf\&sa $=U \& v e d=0$ ahUKEwj41bDVILrTAhVJZ1AKHdCfD50QFggLMAA\&usg=AFQjCNH_v9xIWQ3xKWKaldtDs9vIDG5Kcg. Accessed 23 Apr 2017

United Republic of Tanzania. (2007). Special education unit report. Dar es Salaam: Minisry of Education and Vocational Training.

United Republic of Tanzania. (2010). The persons with disabilities act, 2010. Dar es Salaam.

United republic of Tanznaia (2013). Basic education statistics in Tanzania. http://opendata.go.tz/dataset/a347a392-a08a43da-a26a-cd29f908cecd/resource/515d0c7c-dfe3-4e57-8265-7a36ffc94a5c/download/Idadi-ya-Wanafunzi-katikaShule-za-Awali-kiwilaya-2013.csv. Accessed 16 Apr 2017.

Vygotsky, L. S. (1978). Mind in society: The development of higher psychological processes. Cambridge: Harvard University Press.

Westwood, P. (2011). Commonsense methods for children with special educational needs (6th ed.). New York: Routledge.

\section{Submit your manuscript to a SpringerOpen ${ }^{\circ}$ journal and benefit from:}

- Convenient online submission

Rigorous peer review

Open access: articles freely available online

- High visibility within the field

- Retaining the copyright to your article

Submit your next manuscript at $\boldsymbol{\Delta}$ springeropen.com 